\title{
住宅のバリアフリー化に対する需要と負担の軽減効果に関する研究 ANALYSIS OF DEMAND FOR BARRIER-FREE HOUSE AND EFFECT IN REDUCTION OF BURDEN
}

\author{
佐 藤 信二*, 近 藤 光 男**, 渡辺 公次郎*** \\ Shinji SATO, Akio KONDO and Kojiro WATANABE
}

\begin{abstract}
The study aims to analyze the demand and the effect for the barrier-free house from the economical viewpoint. Firstly, the questionnaire for inhabitant is executed to investigate the willingness to pay for each level of barrier-free. Using these data, the following analysis is executed. The Cobb-Duglass function is used as the demand function. The willingness to pay is used to analyze the effect of reduction of burden. From the results of the analysis related to the effect of the subsidy, regardless of the subsidy level, the demand of the arrangement of handrail was high, and the average of willingness to pay was nearly $1,100,000$ yen.
\end{abstract}

Keywords: Barrier-free House, Willingness to Pay, Demand Curve, Cost Benefit Analysis バリアフリー住宅、支払意思額、需要曲線、費用便益分析

\section{1.はじめに}

厚生統計協会 ${ }^{1)}$ によると、わが国の2001年度の国民医療費は約31兆 3,000 億円で、前年度に比べて約 9,651 億円（前年比 $3.2 \%$ 増）增加してい る。中でも、特に老人医療費は約 15 兆3,950億円（前年比 $8.5 \%$ 増）と、 国民医療費総額の $49 \%$ を占めており、将来の老齢人口増加に伴い、国 民医療費に占める老人医療費の割合の増加が腎念される。

社会生活への参加および自立を妨げる物的障害から高齢者や障害 者を解放しようとするのがバリアフリー化の基本概念である2）。交通 施設、集客施設、公共施設、住宅などにおけるバリアフリー化は、高 跉者や障害者が自立した日常生活を続けるために必要不可欠なもの である。特に、住宅内における高齢者や障害者に対する物的障害を解 消する、住宅のバリアフリー化は、住宅内での不慮の事故防止や、病 気が治癒しても退院できない、いわゆる社会的入院の回避などにも有 用な手段であると考えられる。建設省建設政策研究センターによる試 算 ${ }^{3)}$ では、住宅のバリアフリー化は、それを行わない場合に必要となる 介護、医療費よりも低いコストで可能である、という結果が出ている。 增え続ける老人医療費を抑制するだけでなく、高齢者が住みなれた家 や地域で、他人の手を借りずに自立した日常生活を営むためにも、住 宅のバリアフリー化は重要な高齢者および障害者対策の 1 つである と考えられる。

* 徳島大学大学院工学研究科エコシステム工学専攻 大学院生・学修

** 徳島大学大学院工学研究科エコシステム工学専攻 教授・工博

*** 德島大学大学院工学研究科エコシステム工学専攻 助手・博士 (工学)
そこで本研究では、住宅のバリアフリー化を促進するための施策を 検討するための基礎的資料として、経済的な側面から、住宅のバリア フリー化に対する需要分析と当事者および介護者の負担軽减効果の 分析を行うことを目的とする。需要分析では、住宅のバリアフリー化 に対する需要を、需要関数を用いて表現し、それを用いて補助金導入 による需要の変化を分析する。負担軽減効果の分析では、住宅のバリ アフリー化に対する支払意思額を用いて、当事者の身体的、精神的負 担、および介護者の負担軽減の観点から、その効果を分析する。なお、 これ以降、文中に出てくる「バリアフリー化」とは、特に説明のない 限り「住宅のバリアフリー化」を指すものとする。

\section{2. 既往研究と本研究の特徵}

本章では、バリアフリー化の経済的評価に関する既往研究を概観 し、本研究の特徵を示す。佐藤ら ${ }^{4}$ は、患者24名について入院時と在宅 時の医療・介護費とバリアフリー化の費用を比較したところ、バリア フリー化の方が費用は低いが、自己負担比率が医療・介護費よりも高 いため、バリアフリー化の方が実質的な費用が高くなってしまう。そ のため、バリアフリー化のインセンティブが働きにくいことを指摘し ている。京極ら ${ }^{5)}$ は、高齢者の単身、夫婦世帯について、「自宅に住み 続ける」、「自宅を改筑する」、「バリアフリー住宅に入居する」場 Graduate Student, Dept. of Ecosystem Engineering, The Univ. of Tokushima, M.A. Prof., Dept. of Ecosystem Engineering, The Univ. of Tokushima, Dr. Eng. Research Assoc., Dept. of Ecosystem Engineering, The Univ. of Tokushima, Dr. Eng. 
合の建設費用と介護費用を比較することによって、バリアフリー化に 要する建設費用よりもバリアフリー化による介護費用の軽减効果が 大きいことを示し、バリアフリー住宅への公的融資の必要性を指摘し ている。建設政策研究センター3)は、バリアフリー化に要する費用と、 それによる平均的な介護費用軽減額を世帯あたりで比較し、バリアフ リー化による費用便益比は5.2である、という結果を導出している。ま た、年金住宅福祉協会6)は、バリアフリー化が普及した場合の寝たきり 傾向の低下による公的介護費用削減効果のマク口的試算を行い、4兆 円の利子補給を行らことで、16兆円の削減効果が挙げられることを示 している。

これら既往研究では、バリアフリー化による医療・介護費削減効果 に主眼が置かれているものが多い。それに対して、どういった種類の バリアフリー化にどの程度需要があるのか、またバリアフリー化によ る負担軽隇効果を貨幣価値に換算するとどのくらいになるのか、と いったバリアフリー化の需要と効果を、経済的な観点からみた研究は 筆者の知る限り存在しない。こういった検討は、バリアフリー化を経 済的な面から支援、推進するための基礎的な情報になると考えられ る。本研究では、住民意識調查によりバリアフリー化に対する住民の 支払意思額を調查し、その結果からバリアフリー化に対する需要およ び負担の軽減効果を経済的に分析するものである。

\section{3. わが国におけるバリアフリー化の現状}

詳細な分析に入る前に、わが国におけるバリアフリー化の現状を概 観する。現在、わが国では欧米諸国の2〜4倍と、世界でも例をみない 速度で高齢化が進展している。1994年には、高齢人口が14\%を超え、 本格的な高龄社会に突入した。また、世帯構造をみても全世帯の4割が 高齢者を含む世帯となり、特に高齢者のみ世帯が大幅に増加し全世帯 の2割に達するものと見込まれるり。

建設省が行った住宅需要害態調查 ${ }^{2}$ (1998年)では、住宅を持家 (一 戸建・長屋建、共同建）、借家（公営、公団公社、民間、給与住宅） に分け、「手すり（2ヶ所以上）の設置」「段差のない室内」、「廊下な どが車椅子で通行可能な幅である」の項目を满たしている世帯の割合 を調查している (表1)。その結果によると、同居世帯を除く世帯の高 齿者対応の状況をみると、項目 1 を満足している住宅に住む世帯は $12.4 \%$ 、項目2を満足している住宅に住む世帯は $11.8 \%$ 、項目3を満足し ている住宅に住む世帯は $13.3 \%$ となっている。全ての項目を満たして

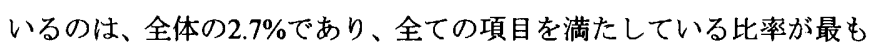
高いのは公営住宅の $10.3 \%$ あった。

以上より、1998年の時点では高齢者に対応した何らかの整備（バリ アフリー化) がなされた住宅に住む世帯は、平均12.5\%程度で、全ての 項目を満たしていた住宅に住む世帯は $2.7 \%$ いなく、バリアフリー化 が遅れていることが伺える。また、この調査によると、住宅内におけ る高齢者の事故による死者数は1998年で約4,500名にのぼっており、こ の点からもバリアフリー化は重要な課題となっている。

次に、徳島県にお抽高齢者介護サービスに関する調査結果 ${ }^{8} に よ$ ると、自宅での介護サービスを希望している高齢者が $60 \%$ 以上にの ぼっている (図1)。また、同調査結果より、どのような住宅改造を望 んでいるのか、という質問については、「便所を洋式にする」が $45 \%$ と最も多く、次いで便所や浴室、廊下に手すりを設置する、段差を無 くす、といった項目が続いている（図2）。洋式便所の改修、手すりの
表1 住宅のバリアフリー化の現状7 [\%]

\begin{tabular}{|c|c|c|c|}
\hline & 手すり(2ヶ所以上) & 段差のない室内 & $\begin{array}{c}\text { 廊下などが車椅子で } \\
\text { 通行可能な幅 }\end{array}$ \\
\hline 持家 & 12.5 & 16.4 & 18.6 \\
\hline 借家 & 8.9 & 13.5 & 10.7 \\
\hline 住宅全体 & 12.4 & 11.8 & 13.3 \\
\hline
\end{tabular}

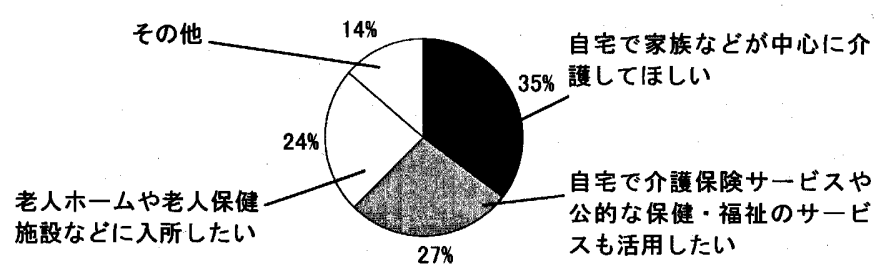

图1高秢者の介護に関する要望 ${ }^{8}$

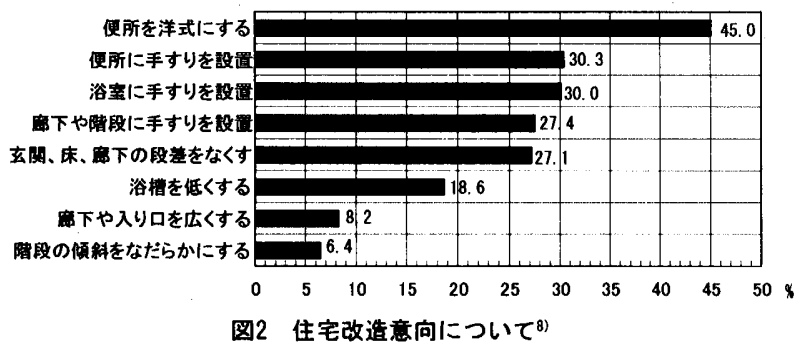

設置、段差の解消など、高齢化に伴う身体変化に対応した住宅改造が 望まれていることがわかる。

\section{4. バリアフリー化の需要分析}

ここではバリアフリー化に対する需要を明らかにすることを目的 として、まずバリアフリー化の価格とそれに対する需要の関係を定式 化し、次にその関数型を住民意識調查のデータを用いて推計する。最 後に、その関数を用いて需要の変化を計量的に分析する。

\section{4-1. 需要関数}

まず、住民のバリアフリー化に対する需要行動の定式化を行う。 家計においては、バリアフリー化によって、家庭内の事故に起因す るけが等が堿少し、それにより医療費や介護の負担が軽减されるな らば、軽减された費用や時間を他の目的に使用することが可能にな る。つまり、バリアフリー化を進める (バリアフリー化の需要のた めの予算をとる）ことによって、家計には上記の効果が発生する。 このことは、バリアフリー化に対するインセンティブとなる。

そこで、家計における効用は、このような効果によっても、もた らされると考えるならば、バリアフリー化の需要は効用関数の要因 (変数) と位置づけることができる。このとき、バリアフリー化の 需要のための予算は、家計における所得制約の中で与えられること になるため、その需要行動も一般の消費者行動として捉えることが できると考えられる。本研究ではバリアフリー化の需要分析を目的 としているため、その需要によって発生する効用以外は、一般財に よるものとしてまとめ、式(1)と式(2)に示す最適化問題を設定した。

効用関数の特定では、その変数であるバリアフリー化の需要と一 般財に対し、それぞれ限界効用が低減するとの仮説が反映できる関 数型として、非線形型のコブ・ダグラス型関数”を用いている。 
目的関数 $U=Z^{\alpha} \cdot Y^{\beta} \rightarrow \max$

制約条件 $I=Z \cdot P z+Y$

$$
\begin{aligned}
& \text { ただし、 } U: \text { バリアフリー化の効用 } \\
& Z: \text { バリアフリー化の需要 } \\
& Y: \text { 一般財 } \\
& I: \text { 所得 } \\
& P z: \text { バリアフリー化の価格 } \\
& \alpha, \beta: \text { パラメータ }
\end{aligned}
$$

パラメータ $\alpha, \beta$ はともに非負で、 $\alpha+\beta=1$ を満たすものとする。ラグ ランジュの未定乗数法を用いて式(1)および式(2)の最適化問題を解く と、式(3)と式(4)が得られる。

$$
\begin{aligned}
& Z \cdot P z=\alpha \cdot I \\
& Y=\beta \cdot I
\end{aligned}
$$

式(3)と式(4)によると、効用関数を構成する2つの変数に対する効用 の重みパラメータ $\alpha$ と $\beta$ は、所得を $\alpha$ と $\beta$ の值の大きさに比例して配分 し、バリアフリー化の需要と一般財のために用いれば、効用を最大化 することを示している。このことから、効用関数にコブ・ダグラス型 の関数を仮定することによって得られる分析結果は意義がある。式(3) より、需要量 $Z$ は次式(5)で表される。

$$
Z=\alpha \cdot \frac{I}{P z}
$$

上式より、バリアフリー化のための投資額 $\alpha \cdot I$ は、価格の高低にか かわらず決定されており、その時の価格によって需要が変化するも のと考えられる。

\section{4-2. 住民意識調查}

需要関数のパラメータを推定するために、バリアフリー化に対する 支払意思額に関する住民意識調查を実施した。調查票の配布部数は 3,000部であり、徳島県内の徳島市、鳴門市、小松島市、松茂町、北島 町、藍住町、板野町、石井町を対象として、人口比に基づいて配布枚 数を決定した。調查時期は2003年11月であり、調查票は、直接訪問に より配布し、郵送回収を行った。その結果、調查票の回収数は374部で あり、回収率は $12.5 \%$ あ゙った。その中から、記載不備などを除いた 164 部を以降の分析で用いる。

調查内容は、まず回答者の属性として、年齢、性別、職業、家族構 成、現在住んでいる住宅のタイプ、住所 (町丁目まで)、年収を質問し た 年収を示す。性別は、男性が $51 \%$ 、女性が49\%であり、年齢は 50 歳代が 最も多く28\%、次に 40 歳代が $25 \%$ となっている。職業は会社員が最も多 く $30.5 \%$ 、次いで主婦と年金生活者が $19 \%$ を占めている。年収は 400 〜 600 万円、200 400万円の範囲が最も多く21\%である。居住地は、徳島 市が最も多く $43.3 \%$ あ゙あ。年齡別に年収をみてみると、30歳以下と 60 歳以上では200〜400万円が、50歳代では、800〜1000万円が最も多い割 合を占めている。

バリアフリー化に対する支払意思額については、表2に示すように バリアフリー化の程度を5つのランクに分類し、各ランクのバリアフ

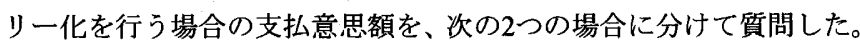
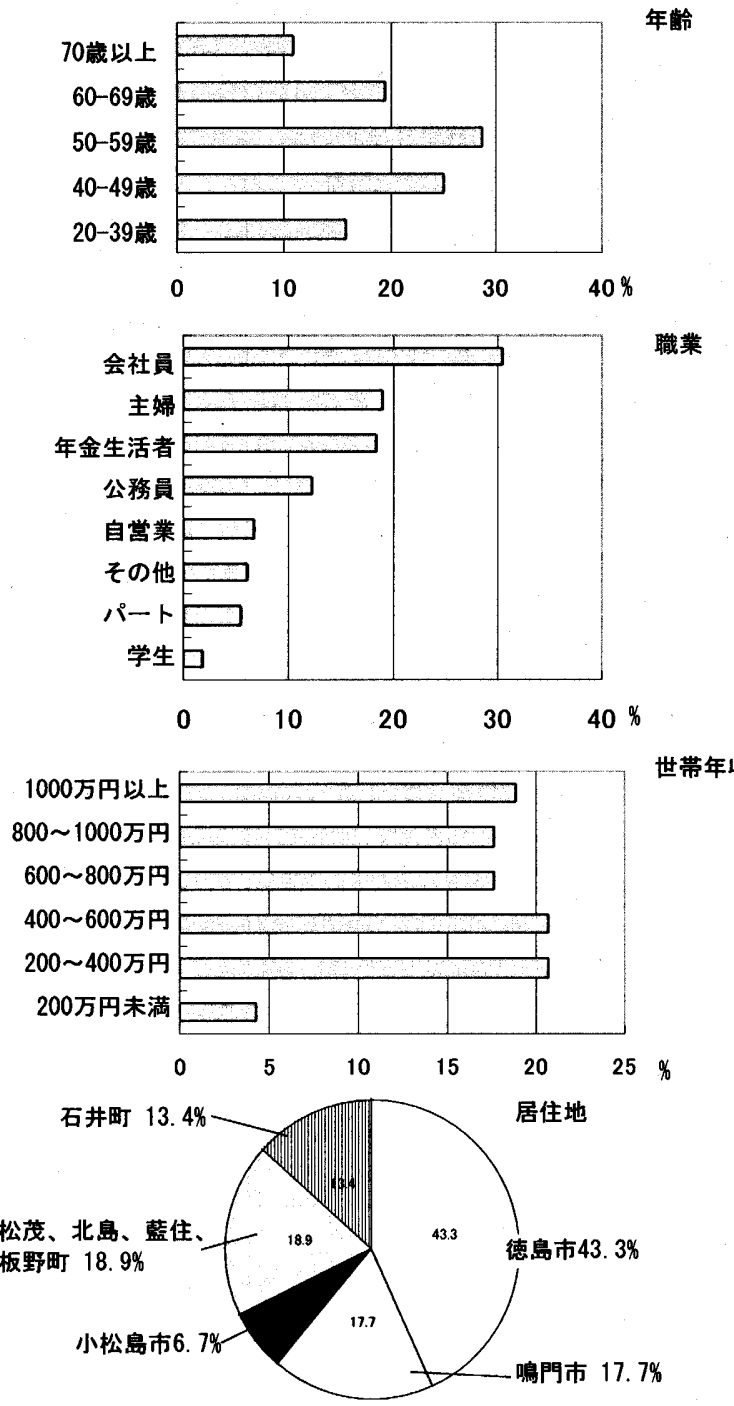

图3 回答者の年龄、瞕業、世帯年収、居住地

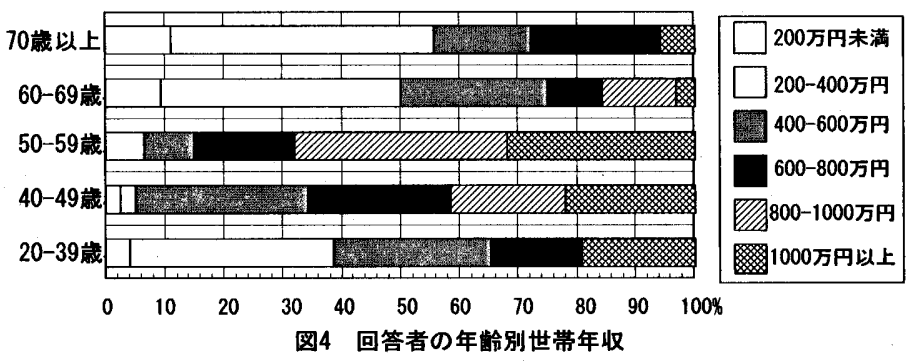

一つ目は、各ランクのバリアフリー化を行うことで「身体的負担の軽 減」、「精神的負担の軽減」、「医療・介護費の軽減」、「移動負担 の軽減」、「介護者負担の軽减」、「交通負担の軽减」、「所得の增 加」、「資産価值の向上」が図られる場合の支払意思額であり、主観 的な価値を経済的な価值に置き換えるためのものである。二つ目は、 これらの負担軽减を総合的にみた場合の支払意思額である。後者はバ リアフリー化に対する需要分析で、前者はバリアフリー化による負担 軽減の効果分析で用いる。調査表の一部を図5に示す。ここで、「障害 物の解消」とは、手すりの設置、玄関の段差の解消、風呂場や洗面所 の障害物の解消の実施を意味する。表2における 
表2 ランク別のバリアフリー化の定義

\begin{tabular}{|c|c|c|c|c|}
\hline & 障害物の解消 & リフト設置 & エレベーター設置 & 手すりのみ設置 \\
\hline ランクA & $\mathrm{O}$ & $\mathrm{O}$ & $\mathrm{O}$ & \\
\hline ランクB & $\mathrm{O}$ & $\times$ & $\mathrm{O}$ & \\
\hline ランクC & $\mathrm{O}$ & $\mathrm{O}$ & $\times$ & \\
\hline ランクD & $\mathrm{O}$ & $\mathrm{x}$ & $\mathrm{x}$ & \\
\hline ランクE & $\times$ & $\times$ & $x$ & 0 \\
\hline
\end{tabular}

（ア）ここからが質問です。回答は、回答例のように表の中にご記入下さい。「身体 的負担の柽隇」の視点から、あなたは住宅のバリアフリー化に対し、いくら支 払っても良いとお考えですか。

\begin{tabular}{|c|c|c|c|c|c|c|c|c|c|}
\hline \multirow{2}{*}{$\begin{array}{l}\text { 住宅バリア } \\
\text { フリー化度 }\end{array}$} & \multicolumn{9}{|c|}{ 支払い意思類（万円） } \\
\hline & 20 & 40 & 60 & 80 & 100 & 120 & 140 & 160 & 180 \\
\hline ランクAの場合 & & & & & & & & & \\
\hline ランク B の場合 & & & & & & & & & \\
\hline ランク Cの場合 & & & & & & & & & \\
\hline ランクDの場合 & & & & : & & & & & \\
\hline ランク $\mathrm{E}$ の場合 & & & & & & & & & \\
\hline
\end{tabular}

図5＼cjkstart住民意識賙査で用いた賙查表（一部）

要素の有無を示している。例えば、ランクAは障害物が無く、しかもリ フトとエレベーターが備わった住宅である。なお、ランクEは最も基本 的なバリアフリー化として、手すりのみが設けられた住宅を想定して いる。手すりの設置場所としては、玄関アプローチ、玄関、廊下、風 呂場、洗面所、トイレ、階段、台所であり、ランク $\mathrm{A} \sim \mathrm{E}$ の住宅全てに 設置されている。この5つのランク設定には、介護保険における要介護 度も考慮している。ランクAは介護度5（最重度の介護を要する状態）、 ランクBは介護度4 (重度の介護を要する状態)、ランクCは介護度3 (中 程度の介護を要する状態）、ランク Dは介護度2（軽度の介護を要する 状態）、ランクEは介護度1（部分的な介護を要する状態）の人が利用 するバリアフリー化を想定している。

\section{4-3. 需要関数の推定}

ランクごとに式(5)のパラメータ $\alpha$ を推定するため、住民意識調査 結果を用いて回帰分析を行った。

ところで、バリアフリー化の需要を考えた場合、社会全体でみたと しても、バリアフリー化を強く望む人 (グループ) と、将来は必要に なると思われるが、現状では住宅がバリアフリー化されていなくても 問題がない人 (グループ) が存在すると考えられる。概ね、前者は高 齢者層であり、後者は非高齢者層に相当するといえよう。一般的に、 これらの 2 つの層の所得に着目すると、高齢者層は、非高齢者層に比 べ所得が低くなっている。以上のことを総合すると、所得の低い高齢 者層はバリアフリー化の需要が強く、所得の高い非高齢者層はその需 要が弱いことが考えられる。そこで、60歳以上を高齢者層、60歳未満 を非高齢者層として分析を行った。所得 $I$ は住民意識調查結果から得 られた高齢者層の世帯年収平均值417万円、および非高齢者層の世帯 年収平均值777万円を用いた。価格 $P z$ を段階的に設定し、その価格に 対して需要する需要者数の割合を需要量 $Z$ とし、回帰分析に用いる步 ンプルとした。回帰分析により得られたパラメータ $\alpha$ 、決定係数、 $\mathrm{t}$ 值 を表3に、推計した需要関数 (ランク $\mathrm{E}$ の場合) を図示したものを図6に 示す。

表3によると、高齢者層、非高龄者層とも、どのランクにおいても決 定係数と $\mathrm{t}$ 值は良好であり、高い推定精度が得られている。 $\alpha$ の值は、
表3 需要関数の推定結果

\begin{tabular}{|c|c|c|c|c|c|}
\hline ランク & 年齝区分 & $\alpha$ & 決定係数 & $\mathrm{t}$ 值 & サンプル数 \\
\hline \multirow{2}{*}{ A } & 非高齢者層 & 0.105 & 0.949 & 15.095 & 13 \\
\hline & 高齡者層 & 0.199 & 0.944 & 14.349 & 13 \\
\hline \multirow{2}{*}{ B } & 非高齢者層 & 0.079 & 0.923 & 12.026 & 13 \\
\hline & 高齡者首 & 0.151 & 0.907 & 10.413 & 12 \\
\hline \multirow{2}{*}{ C } & 非高龄者層 & 0.052 & 0.899 & 9.940 & 12 \\
\hline & 高齢者層 & 0.098 & 0.852 & 7.984 & 12 \\
\hline \multirow{2}{*}{ D } & 非高嘴者層 & 0.030 & 0.906 & 9.828 & 11 \\
\hline & 高齢者層 & 0.060 & 0.865 & 8.428 & 12 \\
\hline \multirow{2}{*}{$E$} & 非高齢者層 & 0.013 & 0.916 & 9.947 & 10 \\
\hline & 高龉者層 & 0.028 & 0.834 & 7.104 & 11 \\
\hline
\end{tabular}

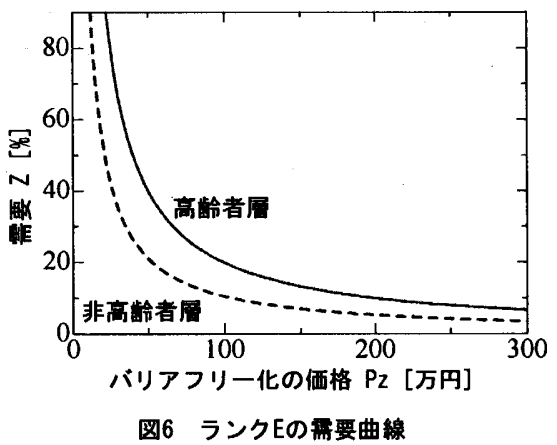

需要曲線（図6）に反映されており、 $a$ が大きいほど同じバリアフリー 化の価格に対して需要が多いことを意味している。このことに基づい て、推定された需要関数をランクごとに高齢者層と非高齢者層で比較 すると、どのランクにおいても、高齢者層の方が $\alpha$ が大きくなってお り、所得が同程度の場合、高齢者層の方が、バリアフリー化の価格が 同じであっても、需要が多いことを表している。以上、所得の低い高 齢者層、および所得の高い非高齢者層におけるバリアフリー化の価格 と需要の関係を精度良く推定することができた。

\section{4-4. パリアフリー化に関する需要分析}

さて、2000年より高齢者に対する住宅改造は原則として介護保険か ら給付されるようになった。介護保険による住宅改造は、申請者の資 産形成防止や貸貸住宅居住者との均衡を考虑して、20万円以内の小規 模なものに限定されている。そのため、增築や廊下の拡幅といった比 較的費用のかかる整備は制約を受ける。また融資制度についても、そ の額は多くの自治体で現状維持か减少傾向にある1)。徳島県では、県産 材住宅（徳島県産の木材を $50 \%$ 以上使用した住宅）に対して1年あたり 20万円（最大 3 年間まで）の補助制度がある。

そこで、バリアフリー化に対する補助金が20万円、60万円、80万円 の場合について、需要シミュレーションを行った。20万円は徳島県よ り 1 年間補助を受けた場合、60万円は徳島県より 3 年間補助を受けた場 合、80万円は徳島県より 3 年間補助を受け、かつ介護保険からも20万円 の補助を受けた場合を想定している。

式(5)において、所得 $I$ は住民意識調查結果から高齢者層の世帯年収 平均值417万円、非高齢者層の世帯年収平均値777万円を、 $\alpha$ は表3の值 を用いて、高齢者層、非高齢者層別に、補助金なし、補助金20万円、 補助金 60 万円、補助金 80 万円の場合の需要 $Z$ を、ランク別に計算した。 ここで、補助金なしの場合のバリアフリー化の価格すなわち、各ラ ンクでバリアフリー化を行う場合に必要となる価格は、リフォーム業 者へのヒアリングおよび建設会社のバリアフリーリフォームに関す 
表4「障害物の解消」の内容と費用

\begin{tabular}{|c|c|c|}
\hline 場所 & 内容 & 概算費用[万円] \\
\hline 玄関(内側) & 土間と床面との段差を小さくする、式台の設置 & 4.5 \\
\hline 玄関(外側) & ポーチと土間の段差解消(スロープ)、玄関ドアの交換 & 50 \\
\hline 階段 & 手摺設鱿、勾配を經くする、足元照明設置 & 42.5 \\
\hline ドア & 引戸に変更、床と数居の段差解消 & 12 \\
\hline 洗面、脱衣室 & $\begin{array}{l}\text { 椅子に座って利用できる洗面台に変更し、床暖房を設 } \\
\text { 置 }\end{array}$ & 27.5 \\
\hline 浴室 & 手摺を取付け、システムバスに変更 & 70 \\
\hline 便所 & 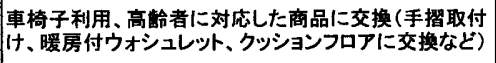 & 22.5 \\
\hline & 竐 & 229 \\
\hline
\end{tabular}

表5 バリアフリー化に対する需要[\%]

\begin{tabular}{|l|r|r|r|r|}
\hline \multirow{2}{*}{} & \multicolumn{2}{|c|}{ 非高齢者䬱 } & \multicolumn{2}{c|}{ 高齢者層 } \\
\cline { 2 - 5 } & ランクD & \multicolumn{1}{|c|}{ ランクE } & ランクD & \multicolumn{1}{c|}{ ランクE } \\
\hline 補助金なし & 10.2 & 9.9 & 10.8 & 11.6 \\
\hline 補助金20万円 & 11.1 & 12.3 & 11.9 & 14.5 \\
\hline 補助金60万円 & 13.8 & 24.6 & 14.7 & 29.0 \\
\hline 補助金80万円 & 15.6 & 49.3 & 16.7 & 58.1 \\
\hline
\end{tabular}

る資料を参考に、筆者らが設定したものである。リフトについては 150 万円、ホームエレベーターについては300万円で、両方とも設置価格込 みとしている。これらはカタログ等から標準的と考えられる商品を選 んでいる。ランクEは手すりの設置だけであるが、住宅全体に手すりを 設置すると想定しているため約100万円に設定している。ランクA〜D の「障害物の解消」については表4に示す内容を想定している。これら の金額は、バリアフリー化の程度および住宅の広さによっても大きく 左右されるが、本研究では、延床面積 $165 \mathrm{~m}^{2}$ 、価格 2,500 万円程度の住宅 を想定して金額を設定した。まとめると、バリアフリー化の価格は、 ランクAが679万円、ランクBは529万円、ランクCが379万円、ランクD が229万円、ランクEが100万円となる。

表5に算定したバリアフリー化に対する需要を示す。ランク A〜Cに ついては、設置費用が高額なため、補助金を導入した場合でも $14 \%$ 程 度であり、それほど大きな効果は見られなかったことから、ここでは ランクDとEの結果のみを示す。

表5より、各年代、ランクとも補助金導入により需要は上昇している ことから、バリアフリー化に対する補助金の効果は一定程度みられ る。特にランクEは、補助金なしの場合に比べ、補助金が80万円になっ た場合は、非高齢者層では需要が9.9\%から $49.3 \%$ 、高跉者層では $11.6 \%$ から58.1\%と、他のランクに比べて大幅な需要増がみられる。ランク $\mathrm{E}$ は手すりのみを設置する最も軽微な改造であるが、それでも補助金な しだと 100 万円必要である。補助金を 80 万円にした場合、自己負担分は 20万円になるが、その程度であればバリアフリー化を行いたい、とい う需要があることが分かった。住宅金融公庫の資料 ${ }^{10}$ によると、新筑 戸建住宅における手すりの設置率は、階段 $91.9 \%$ 、浴室 $86.1 \%$ 、トイレ $54.9 \%$ 、廊下 $5.6 \%$ 、玄関 $31.2 \%$ であり、廊下と玄関は低いものの、階段、 浴室、トイレは、新筑住宅の半数以上が手すりを設置しており、一般 的にも手すり設置の需要は高いと考えられる。

\section{5. バリアフリー化による負担の軽隇効果}

前章で行った住民意識調查結果を用いて、バリアフリー化による負 担の軽減効果を支払意思額に基づいて分析する。ここで取り上げる負 担は、当事者の身体的、精神的負担および介護者の負担である。それ
ぞれの負担に関し、バリアフリー化に対する平均支払意思額を経済的 効果として算出するが、そのためには、バリアフリー化に対する提示 金額と許諾率との関係を表す、許諾率関数を推定する必要がある。

\section{5-1. 平均支払意思額の推計方法}

許諾率は、提示額の増加に従って低減すると考えられる。本分析で は、従来の分析結果 ${ }^{11)}$ を参考にして、減少の比率が聥減すると仮定し、 式(6)のような指数型の許諾率関数を設定した。なお、式(6)の関数型の 概形は図7のようになる。

$$
\begin{aligned}
& f(w)=k \cdot a_{1}^{\delta_{a 1}} \cdot a_{2}^{\delta_{a 2}} \cdot a_{3}^{\delta_{a 3}} \cdot e^{-\gamma w} \\
& \text { ただし、 } w \text { : 提示額 } \\
& k, \gamma: \text { パラメータ }(k, \gamma>0) \\
& a_{1}, a_{2}, a_{3} \text { ：「障害物の解消」、「リフトの設置」、「エレベー } \\
& \text { ターの設置」に対する重みのパラメータ } \\
& \delta_{a 1}, \delta_{a 2}, \delta_{a 3} \text { : ダミー変数で、「障害物の解消」がなされてい }
\end{aligned}
$$

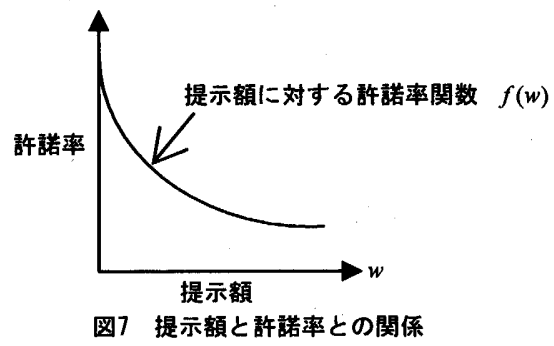

なお、式(6)の $a_{1}, a_{2}, a_{3}$ 以外の部分は、最も基本的なバリアフリー化 として想定したランク Eの場合の関数であり、それに「障害物の解消」、 「リフトの設置」、「ェレベーターの設置」がなされているかに态じ て係数が掛け合わされていく。

これより、式(6)を用いてランク $\mathrm{A} の$ 場合の許諾率関数は「障害物の 解消」、「リフトの設置」、「エレベーターの設置」すべてが含まれ るので、次式(7)となる。

$f_{A}(w)=k \cdot a_{1} \cdot a_{2} \cdot a_{3} \cdot e^{-\gamma w}$

同様に、ランクBからランクEは、次のようになる。

$f_{B}(w)=k \cdot a_{1} \cdot a_{3} \cdot e^{-\gamma w}$

$f_{C}(w)=k \cdot a_{1} \cdot a_{2} \cdot e^{-\gamma w}$

$f_{D}(w)=k \cdot a_{1} \cdot e^{-\gamma w}$

$f_{E}(w)=k \cdot e^{-\gamma w}$

図7より平均支払意思額は、許諾率関数を0〜のの範囲で積分したも のに相当する。よって、各ランクの平均支払意思額 $W$ は式(12) (16)の ようになる。

$W_{A}=\int_{0}^{\infty} f_{A}(w) d w=\frac{k \cdot a_{1} \cdot a_{2} \cdot a_{3}}{\gamma}$ 
表6 負担の軽減効果分析の結果

\begin{tabular}{|c|c|c|c|c|c|c|c|c|c|c|c|}
\hline & \multicolumn{5}{|c|}{ 式(6)のパラメータ } & \multirow{2}{*}{ 決定係数 } & \multicolumn{5}{|c|}{$\mathrm{t}$ 値 } \\
\hline & $k$ & $\gamma$ & $a_{1}$ & $a_{2}$ & $a_{3}$ & & $k$ & $\gamma$ & $a_{1}$ & $a_{2}$ & $a_{3}$ \\
\hline $\begin{array}{l}\text { 当事者の身体 } \\
\text { 的負担の軽減 }\end{array}$ & 1.396 & 1. $948 \times 10^{-6}$ & 1.589 & 1.015 & 1.137 & 0.896 & 14.048 & 47.351 & 14.511 & 0.612 & 3.733 \\
\hline $\begin{array}{l}\text { 当事者の精神 } \\
\text { 的負担の軽減 }\end{array}$ & 1.490 & 2. $219 \times 10^{-6}$ & 1.601 & 1.045 & 1.172 & 0.894 & 15.706 & 51.404 & 14.071 & 1.710 & 4.615 \\
\hline $\begin{array}{c}\text { 介護者の負担 } \\
\text { の軽減 }\end{array}$ & 1.501 & 1. $984 \times 10^{-6}$ & 1.547 & 1.008 & 1.079 & 0.888 & 16.097 & 47.941 & 13.374 & 0.310 & 2.289 \\
\hline
\end{tabular}

表7負担の軽減に対する平均支払意思額推計結果 [万円]

\begin{tabular}{|c|r|r|r|r|r|}
\hline & \multicolumn{5}{|c|}{ ランク } \\
\cline { 2 - 6 } & \multicolumn{1}{|c|}{ A } & \multicolumn{1}{|c|}{ B } & \multicolumn{1}{c|}{ C } & \multicolumn{1}{c|}{ D } & \multicolumn{1}{c|}{ E } \\
\hline $\begin{array}{r}\text { 当事者の身体 } \\
\text { 的負担の軽減 }\end{array}$ & 131 & 129 & 116 & 114 & 72 \\
\hline $\begin{array}{c}\text { 当事者の精神 } \\
\text { 的負担の軽減 }\end{array}$ & 132 & 126 & 112 & 107 & 67 \\
\hline $\begin{array}{c}\text { 介護者の負担 } \\
\text { の軽減 }\end{array}$ & 127 & 126 & 118 & 117 & 76 \\
\hline
\end{tabular}

$W_{B}=\int_{0}^{\infty} f_{B}(w) d w=\frac{k \cdot a_{1} \cdot a_{3}}{\gamma}$

$W_{C}=\int_{0}^{\infty} f_{C}(w) d w=\frac{k \cdot a_{1} \cdot a_{2}}{\gamma}$

$W_{D}=\int_{0}^{\infty} f_{D}(w) d w=\frac{k \cdot a_{1}}{\gamma}$

$W_{E}=\int_{0}^{\infty} f_{E}(w) d w=\frac{k}{\gamma}$

\section{5-2. 負担の軽減効果に対する平均支払意思額の推計}

次に、この手法により平均支払意思額の推計を行う。調查結果を用 いて式(6)のパラメータを回帰分析により推計したところ、表6のよう な結果が得られた。表6の決定係数および値により分析結果の精度を 確認した後、表6の各パラメータを式(12) (16)に代入し、各ランクの 支払意思額を求めた。その結果を表7に示す。

表6によると、3つとも決定係数が 0.88 以上と比較的高く、 $\mathrm{t}$ 值も「リ フトの設置」に対する重み $a_{2}$ が低いものの、それ以外は問題ない值が 得られている。

表7より、負担の軽减による平均支払意思額は、バリアフリー化の程 度が上がる、すなわち住宅の環境改善度が上がるにつれて大きくなっ ている。これは、住民が住宅の環境改善を期待しているためであると 考えられる。また、ランクB以上の改善になると金額はあまり変わらな くなってきているが、これは住民がある一定以上の金額を支払う意思 がないためであると思われる。

\section{5-3. 在宅介護費用との比較}

以上、住民意識調査をもとに、バリアフリー化による負担軽减につ いて分析を行った。ここでは、得られた結果とバリアフリー化を行わ ない場合に必要となることが予想される在宅介護費用とを比較する ことで、その有効性を示す。

在宅介護費用は、利用者の健康状態やホームヘルパーの利用時間 数、デイケアの回数、利用する介護用品の種類などによって大きく 異なる。そのため、ここでは筆者らが徳島市で取材した実際のケー
表8 年間在宅介護費用

\begin{tabular}{|c|r|}
\hline 種目 & 経費[円/年] \\
\hline 在宅医療費 & 154,950 \\
\hline 在宅介護費(通所によるデイケア) & 37,980 \\
\hline 介護用品賟入費 & 240,000 \\
\hline 合計 & 432,930 \\
\hline
\end{tabular}

スについての介護費用と比較する。

A氏（男性）は、77歳の1990年9月に心筇梗塞により自宅で倒れ、 約 1 年間入院、退院後、自宅療養中に廊下の敷居につまずいて転倒し て胸椎を骨折し、いわゆる「寝たきり」状態が約 12 年間続いた。表8 に、A氏が必要とした在宅介護費用を示す。なお、A氏が介護を受け ていた 1991年〜2003年の間には、保険制度の改正等による医療費負 担の変化があり、在宅医療費については年ごとで若干の違いがあ る。そのため、表8には2001年分の費用を示している。

4-4.でも述べたように、規模の違いはあるものの、手すりのみを設 置するランク Eのバリアフリー化の価格は約100万円である。住宅内 の転倒事故理由には、本人の健康状態や不注意など住宅とはあまり 関係ない場合もあるが、最低限、手寸りが設置されていれば、A氏は 転倒事故に遭遇しなかったかもしれない。住宅改修の程度や、ホー ムヘルパー、デイケアの利用回数など利用者の状態により費用は変 化してくるため一概にはいえないものの、このケースの場合、単純 に12年間分を合算してみても約 520 万円かかっている。ランク リアフリー化の価格100万円と比較してみても、バリアフリー化の有 効性がうかがえる。

\section{6. 結論}

本研究では、住民意識調查をもとに、バリアフリー化の需要と、 バリアフリー化による負担の軽減効果について分析を行った。分析 結果に対する考察と成果をまとめて結論とする。

(1)バリアフリー化に対する住民の需要行動をコブ・ダグラス型関数 を用いて特定化した最適化問題として表し、需要を所得とバリア フリー化の価格による関数として表すことができた。高踚者層、 非高齢者層別に需要を推定したところ、どのランクにおいても高 齢者層の方が、バリアフリー化の価格が同じであっても、需要が 多いことが精度よく示された。

(2)その需要関数を用いて、補助金導入によるバリアフリー化の需要 を算定したところ、ランク A〜Cについては、補助金を導入した場 合でも需要が $14 \%$ 程度とそれほど高くはなかったが、ランク D、E については、補助金を60万円、80万円にした場合、需要がある程 度見込めることが分かった。

(3)バリアフリー化による負担軽減についての効果分析では、住宅の バリアフリー化の環境改善度が大きくなるにつれて負担軽減効果 が大きくなる傾向にあるものの、ある一定以上の改善になると、 
金額は大きくは上昇せずに約110万円〜 130万円程度であった。こ れより、効果としては、最大約110万円〜 130 万円程度であること が分かった。

(4)バリアフリー化の価格と、在宅介護費用を比較してみたところ、

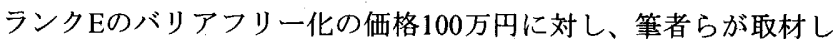
たケースの在宅介護費用は年額約 43 万円であり、バリアフリー化 の有効性がうかがえた。

(5)今後の課題として、まずはバリアフリー化のための費用の設定方 法の改善があげられる。住宅の形式（戸建て、集合住宅など） や、広さ、バリアフリ一化の程度によって価格は大きく変わって くる。今回の分析では、バリアフリー化のための費用を表4に示す ように戸建て住宅を想定して設定した。この費用設定により推定 される需要が変化するため、より実状に即した条件を想定して分 析を行うことが、より現実に近い需要を推定するためにも必要で ある。さらには、今回はバリアフリー化の需要と負担軽減効果の 分析手法を提案するにとどまったが、この成果を踏まえて、バリ アフリー化による住民のQOL（生活の質）向上を経済的に評価す る手法の開発も、今後の課題として考えられよう。

\section{謝辞}

本研究を実施するにあたり、住民意識調查票の作成および統計解析 に関して多くの協力を頂いた徳島大学大学院工学研究科エコシステ $\Delta 工$ 学専攻博士前期課程の岡崎秀樹君、医療費に関寸る情報提供を頂 いた藤井医院（徳島市）、介護費の情報提供を頂いた老人ホーム白寿 園（徳島市）に対して深甚なる謝意を表します。

\section{参考文献}

1) 国民衛生の動向・厚生の指標、臨時増刊・第50巻第9号、 2003年

2) 巽和夫編 : 現代八ウジング用語辞典、彰国社、1993年

3) 建設省建設政策研究センター：高齢者住宅整備による介護費用軽減効果、 PRCノート第4号、1993年

4) 佐藤智ほか : 在宅ケアの経済的評価の研究、社会保険旬報No.1612、1991年 5) 京極高宣ほか：高齢化対応住宅と介護コスト、住宅金融月報、1991年 6) 年金住宅福祉協会編 : 高齢化対応住宅整備促進による経済効果、1994年 7) 建設省住宅局監修 : 住宅需要の動向 平成10年住宅需要実態調査の結果、日 本住宅協会、1999年

8 徳島県高齢者実態調査報告書、2002年

9) Alonso, W.: Location and Land Use, Harvard University Press, 1964 (折下功訳 : 土地と土地利用、朝倉書店、1964年)

10) 住宅金融公庫 : 住宅・建築主要データー戸建住宅編一、2002年

11) 肥田野登 編著：環境と行政の経済評価-CVM (仮想市場法) マニュア ル、勁草書房、1999年
注釈

注1) 住民意識調査結果が一般的であるかどうかを判断するために、回答者の性 別、居住地、年齢を、地域住民のそれと比較した（表9）。これによると、住 民意識調查回答者と、地域住民全体の比率はそれほど乘離しておらず、特異な データではないことが分かる。

表9 住民意識調查回答者と地域住民との比較

\begin{tabular}{|c|c|c|c|}
\hline & & 地域住民の比率[\%] & $\begin{array}{c}\text { 住民意識調查回答 } \\
\text { 者の比率[\%] }\end{array}$ \\
\hline \multirow{6}{*}{ 居住地 } & 德島市 & 55.7 & 43.3 \\
\hline & 鳴門市 & 13.4 & 17.7 \\
\hline & 小松島市 & 8.8 & 6.7 \\
\hline & $\begin{array}{l}\text { 板野郡 (松茂町、北島 } \\
\text { 町、藍住町、板野町) } \\
\end{array}$ & 16.5 & 18.9 \\
\hline & 石井町 & 5.5 & 13.4 \\
\hline & 合㖕 & 100 & 100 \\
\hline \multirow{3}{*}{ 性別 } & 男性 & 46.6 & 51.2 \\
\hline & 女性 & 53.4 & 48.8 \\
\hline & 合計 & 100 & 100 \\
\hline \multirow{6}{*}{ 年齢 } & 20３0歳代 & 32.4 & 15.9 \\
\hline & 40藏代 & 15.4 & 25.0 \\
\hline & 50减代 & 19.1 & 28.7 \\
\hline & 60歳代 & 14.8 & 19.5 \\
\hline & 70歳以上 & 18.2 & 11.0 \\
\hline & 合計 & 100 & 100 \\
\hline
\end{tabular}

(2004年 7 月 9 日原稿受理， 2005 年 2 月 25 日採用決定 